\title{
SMS: Tool for L2 Vocabulary Retention and Reading Comprehension Ability
}

\author{
Khalil Motallebzadeh \\ Department of English, Torbat-e-Heydareih Branch, Islamic Azad University, Torbat-e-Heydareih, Iran \\ Email: k.motalleb@iautorbat.ac.ir, kmotallebz@gmail.com \\ Razyeh Ganjali \\ Islamic Azad University (IAU), Mashhad Branch, Iran \\ Email:r.88.ganjali@gmail.com
}

\begin{abstract}
Mobile phones are the new addition to the information and communication technologies (ITC) for learning. The purpose of this study was to examine the effects of SMS on vocabulary retention and reading comprehension ability of Iranian EFL learners. Forty university students were assigned into experimental and control groups. The participants in experimental group received English words as well as definitions and example sentences through SMS in a spaced and scheduled pattern of delivery three times a week throughout 16 sessions while those in control group were taught new words though conventional board and paper technique for the same period. The participants were assessed biweekly. Results of t-test analysis indicated that participants in SMS group could significantly outperform those in control group. The results of this study can also provide pedagogical implications for utilizing SMS as an effective and flexible learning tool.
\end{abstract}

Index Terms-Short Message Service (SMS), Mobile Assisted Language Learning (MALL), Technology Enhanced Language Learning (TELL), vocabulary retention

\section{INTRODUCTION}

Mobile phones are particularly useful mini-computers that fit in student's pocket, are always with them, and are nearly always on (Prensky, 2005). Whereas the introduction of mobile phones in different parts of the world such as Middle East region keeps climbing and short message service (SMS) is being widely used by youth today as a means of communication, not many researchers have explored the application of the short message service in second language. As Beasley (2009) maintains "Text messaging has become a way of life for many in the 21 st century" (p. 89).

In most Asian countries where English is a foreign language, EFL learners face the challenge of lacking exposure to English since for the majority, the class is the only occasion to use English. In addition, there are only limited hours per week for the English course in most schools and universities. In such conditions, teachers should make difficult choices about how to use this limited time to promote language learning. Here, there seems an urgent need to find an effective self-study approach for the students to develop their communication skills as well as enlarge their vocabulary size.

An abundance of evidence from some researches suggest that mobile learning (m-learning) has potential in providing EFL learners with large exposure to the target content as learners can do self-learning anytime and anywhere with the assistance provided by mobile technology (Thornton and Houser, 2005; Chinnery, 2006). A wealth of research has documented the strength of the relationship between vocabulary and reading comprehension ability. Given the close relationship between ESL/EFL learners' vocabulary command and their ability to understand English readings, many researchers have been searching for ways to effectively enhance students' acquisition and retention of new vocabulary knowledge. As Thornbury (2004) indicated, two factors determine retention: first those words that are easy to learn are better retained. Second, those words that are learned over spaced learning sessions are retained better than words that are learned in concentrated burst.

The researchers in this study believe that SMS can help extend learners' opportunities in meaningful ways and provides better conditions for learning vocabulary. With that in mind, they tried to examine the effect of SMS, benefits from personal, informal, situated and context-aware learning on vocabulary retention and its relation to reading comprehension ability of Iranian lower-intermediate EFL learners. They also investigated the participants' attitudes toward learning vocabulary via SMS.

\section{REVIEW OF LITERATURE}

\section{A. Technology Enhanced Language Learning}

As Chabra and Figueiredo (2002) maintain, m-learning is the ability to receive learning anytime, anywhere, and on any device. Learning through SMS resides in m-learning and can be considered as a part of the world of e-learning. SMS also refers, as Anohina (2005) believes, to the use of technology for learning in a broad sense. He also adds that 
SMS "encompasses educational processes carried out in compliance with different theoretical models pursued using different educational methods and is, normally, based on activities that take place via any electronic medium" (p. 94). It is also claimed that employing mobiles for learning can assist students' motivation, encourage a sense of responsibility, help organizational skills, act as reference tools, and help track students' progress and assessment (Smith and Kent, 2003).

Rozgein (2008) stated that technology enhanced language learning (TELL) motivates students by letting them decide about their study time, the conditions they will run the tasks, and organize their study process regardless of whether the other participants of the course follow the same line. As Thornton and Houser (2005) claim, "mobile phones enhance regular study, lead to more exposure to the target words and more vocabulary gains than the detailed presentation of the lessons do" (p. 216). Their findings are in accordance with the empirical evidence in the cognitive psychological research proposing hat constant and distributed practice have a more beneficial effect on memory and learning than massed practice.

Cavus and Ibrahim (2009) investigated the use of wireless technologies in education with particular reference to the potential of learning new technical English language words using SMS. The system, developed by the authors and called mobile learning tool (MOLT), was tested with 45 1st-year undergraduate students. During the experiment, new words and their meanings were sent to students throughout the day in half hourly intervals and their learning abilities were assessed by performing on tests before and after the experiment. The results showed that students "enjoyed and learned new words with the help of their mobile phones" (p. 89).

In another research, Lu (2008) examined the effect of SMS vocabulary lessons of limited lexical information on the small screens of mobile phones. As he reports, the participants recognized more vocabulary during the post-test after reading the regular and brief SMS lessons than they did after reading the relatively more detailed print material. In a similar program developed for Italian learners in Australia, Levy and Kennedy (2005), found that sending English words and idioms via can enhance the participants' recall of the given words. Also, in an innovative project on using mobile phones to teach English at a Japanese university, Thorton and Houser (2004) focused on providing English vocabulary instruction by SMS. The results indicated that the students in SMS group learned over twice the number of words as the students in web and paper groups.

\section{B. Merits of SMS in Education}

Lomine and Buckingham (2009) listed a series of advantages of employing SMS in educational contexts. As they insert, SMS:

- is quick, discrete, to the point, and inexpensive.

- improves students' motivation and retention and involve them more actively

- requires little or no familiarization or training.

Cavus (2009) also maintains that learners' interest in using mobile phones can help them learn new words. He adds that one of the reasons could be the joy they get from using SMS as a "flexible tool into their learning" (p. 76). Meanwhile, he believes that the increase in vocabulary retention via mobile phone-based teaching systems can be due to the positive attitude toward learning vocabulary via SMS.

To achieve the goals of the present quasi-experimental study, the following research question was posed:

Q1. Does short message service (SMS) have any effect on vocabulary retention and reading comprehension ability of Iranian lower-intermediate EFL learners?

To come up with reasonable results on the basis of the aforementioned research question, the following null hypothesis was proposed:

HO1. SMS does not have any significant effect on vocabulary retention and reading comprehension ability of Iranian lower-intermediate EFL learners.

\section{METHOD}

\section{A. Participants}

The participants were selected from 90 lower-intermediate EFL adult learners who took general English course at Sama College, affiliated to Islamic Azad University (IAU) of Mashhad, Iran. Due to the gender segregation rules in Sama College, only female students participated in this project. The participants' age ranged from 19 to 25 . Having administered a test of homogeneity, the researchers could finally select 40 students for the purpose of this study. The participants were randomly assigned to two experimental and control groups. It should be stated that all participants attended the course regularly but six students (three in each group) missed the final exam. Hence, scores for 34 subjects were taken into statistical analysis.

\section{B. Instrumentation}

To collect the required data, several instruments were employed in this study:

(1) Nelson Test. In order to make sure that all participants were homogeneous and truly at the same level of language proficiency, the Nelson Test (100A) developed by Fowler, W.S. \& Coe, N. (1976) was administered. The test contained 50 items. The reliability index of this test was estimated through Cronbach's Alpha as .824 . 
(2) Researchers-Made Test Battery. In order to assess the participants' level of achievement throughout the study, an English general proficiency test battery was developed by the researchers including vocabulary (10 items) and reading comprehension (20 items) subtests. The participants took the test before and after the treatment as the study pretest and posttest. The vocabularies were selected from among those practiced during the course. The reading section of the test included four authentic passages inserted with the words practices in the study. This test battery was piloted with a group of similar test-takers at the Islamic Azad University, Mashhad branch. Cronbach's Alpha formula for multiple choice items and Kuder-Richardson formula 21 (KR-21) for binary items were calculated; the results showed a reliability index of .818 and .712 , respectively.

Procedures

To ensure the homogeneity of the participants at the outset of the study, a Nelson Test was administered to 90 female students studying at different majors in Sama Collage, Mashhad, Iran. Having analyzed the data, the researchers selected forty participants $(\mathrm{N}=40)$ for the purpose of this study. When asked for their attitudes toward learning through SMS, all participants expressed neither positive nor negative opinions about learning vocabulary via SMS. Therefore, they were randomly assigned into two experimental $(\mathrm{N}=20)$ and control $(\mathrm{N}=20)$ groups.

In the next phase of the study, the participants in both groups took a pretest. During 16 sessions of treatment, 50 English words followed by definitions and example sentences were presented to the participants in experimental group through SMS. These messages were delivered in a spaced and scheduled pattern of delivery: three times a week on even days at 9.00 p.m. Each message contained three to four words as well as synonyms and examples. Totally, 16 messages were sent during five weeks of treatment. The sent descriptions and examples were as short as possible so that the recipients could read these messages on their small screens without having to scroll down many times. In control group, the participants were given a list of words on paper followed by definitions and example sentences three times a week. It is worth mentioning that due to personal problems five participants (three in control group and two in experimental group) dropped the course. To remove the participant effect from the study in experimental group, one student's score was randomly removed from the final results of the study. Having finished the treatment (five weeks, 16 sessions), the participants in both groups $(\mathrm{N}=34)$ sat for the posttest. The researchers administered the pretest as posttest to see the effects of the treatment throughout the study.

\section{RESULTS AND DISCUSSIONS}

Having collected the required data based on the mentioned data collection instruments and procedures, the researchers conducted the analysis of data and tested the hypothesis formulated for the present study.

\section{A. Results of Nelson Test as the Homogenizing Instrument}

To check the homogeneity of the total participants $(\mathrm{N}=90)$, the Nelson Test, version (100A) was administered. Table 1 illustrates the descriptive statistics of participants' scores.

TABLE 1:

RESULTS OF DESCRIPTIVE STATISTICS FOR NELSON AS HOMOGENIZING TEST

\begin{tabular}{llll}
\hline Test & Mean & SD & N \\
\hline Nelson & 22.72 & 6.17 & 40 \\
\hline
\end{tabular}

As the results in Table 1 show, mean is 22.72 and the standard deviation is 6.17 . Here, only participants $(\mathrm{N}=40)$ whose scores fall within one standard deviation below and above the mean, i.e. between 16.55 and 28.89 were found valid to be included as the subjects of this study in control and experimental groups. The other participants $(\mathrm{N}=50)$ were found missing and were excluded from the study. Meanwhile, to ensure true homogeneity of the participants $(\mathrm{N}=40)$ in control $(\mathrm{N}=20)$ and experimental $(\mathrm{N}=20)$ groups, an independent-sample t-test was conducted, (see Table 2).

TABLE 2:

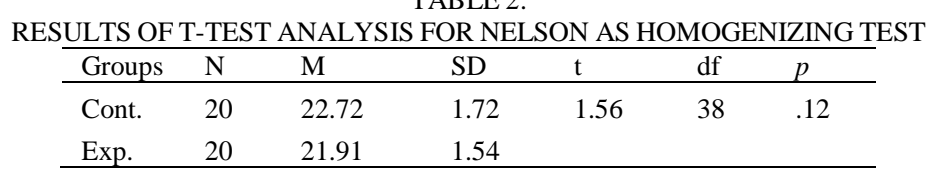

As the results of Table 2 shows, there is no statistically significant difference [t $(38)=.1 .56, \mathrm{p}=.12$ (two-tailed)] between control $(\mathrm{M}=22.72, \mathrm{SD}=1.72)$ and experimental $(\mathrm{M}=1.91, \mathrm{SD}=1.54)$ groups with regard to language proficiency which confirms the homogeneity of the participants at the outset of the study.

\section{B. Results of Researchers-made Reliability}

To ensure that the researchers-made test is reliable, an analysis was done employing Cronbach's Alpha to estimate the reliability indexes of vocabulary and reading comprehension sections of the pretest. As Table 3 indicates, both sections of the pretest enjoy a relatively high reliability $(\alpha=.818$ for vocabulary and $\alpha=.815$ for reading comprehension). 
TABLE 3:

RESULTS OF RELIABILITY OF PRETEST

\begin{tabular}{lll}
\hline Test Section & Cronbach's Alpha & No of Items \\
\hline Vocabulary & .818 & 10 \\
\hline Reading Comprehension & .815 & 20 \\
\hline
\end{tabular}

\section{Results of Study Pretest}

To compare the participants' performances on the researchers-made test in control and experimental groups at the outset of the study, an independent-sample t-test was conducted, (see Table 4).

TABLE 4:

RESULTS OF T-TEST ANALYSIS FOR STUDY PRETEST

\begin{tabular}{|c|c|c|c|c|c|c|}
\hline Groups & $\mathrm{N}$ & $\mathrm{M}$ & SD & $\mathrm{t}$ & $\mathrm{df}$ & $p$ \\
\hline Exp. & 17 & 9.00 & 3.82 & 1.02 & 32 & .31 \\
\hline Cont. & 17 & 7.78 & 3.08 & & & \\
\hline
\end{tabular}

As Table 4 shows, participants in both experimental (SMS) group $(\mathrm{M}=9.00, \mathrm{SD}=3.82)$ and control (paper) group $(\mathrm{M}=7.8, \mathrm{SD}=3.08)$ have achieved low means in pretest, indicating that they were unfamiliar with words used in the vocabulary and reading comprehension sections of the test. In addition, the results reveal no significant difference [ $\mathrm{t}(32)$ $=1.02, \mathrm{p}=.31$ (two-tailed)] between the two groups, showing that both experimental and control groups are similar before the treatment begins.

\section{Results of Study Posttest}

As mentioned in instrumentation, participants in control and experimental groups took the same pretest as the study posttest. A t-test analysis was conducted to compare their scores. Table 5 shows the results for this analysis.

TABLE 5:

RESULTS OF T-TEST ANALYSIS FOR STUDY POSTTEST

\begin{tabular}{lllllll}
\hline Groups & $\mathrm{N}$ & $\mathrm{M}$ & $\mathrm{SD}$ & $\mathrm{t}$ & $\mathrm{df}$ & $P$ \\
\hline Exp. & 17 & 28.76 & 3.84 & 9.24 & 32 & .00 \\
Cont. & 17 & 17.17 & 3.45 & & & \\
\hline
\end{tabular}

As Table 5 reveals, participants in experimental $(\mathrm{SMS})$ group $(\mathrm{M}=28.76, \mathrm{SD}=3.84)$ significantly outperformed $[\mathrm{t}$ $(32)=9.24, p=.00$ (two-tailed) $]$ those in control (paper) group $(\mathrm{M}=17.17, \mathrm{SD}=3.45)$ in vocabulary retention and reading comprehension. The results also indicate that the vocabularies acquired through SMS can also affect the improvement of reading comprehension ability of Iranian lower-intermediate EFL learners.

\section{CONCLUSIONS}

As the findings of this study demonstrate, mobile phones as tool and SMS as an application can facilitate certain forms of learning. Since the text messages can be easily sent at predetermined times and intervals, they can be stored systematically and accessible for later retrievals. According to the results of this study, participants in SMS group could significantly outperform the ones in conventional/paper group, confirming the results found by Lu (2008) and Hulstijn and Laufer (2001) stating mobile phones can be an effective medium for self-learning L2 vocabulary. The obtained results also showed that acquiring vocabularies sent through SMS can be effective in improving learners' reading comprehension scores.

Besides, the findings of this study may have some hints for English teachers and educators. EFL teachers can be encouraged to employ SMS as a supporting learning tool to facilitate vocabulary instruction. More studies, however, are required to determine the role of mobile phones inside and outside of the classrooms such as their role in developing interactive communications between the teacher and the learners. In case SMS is used properly, teachers can devote the constrained class time to other productive skills such as listening or writing. The results of this and similar studies imply that from now on the teachers will not have to begin their teaching with "Please switch your mobiles off"; instead, they can begin with "Switch your mobiles on, please".

\section{ACKNOWLEDGEMENTS}

We would like to thank three anonymous reviewers for their helpful comments on the earlier draft of this paper.

\section{REFERENCES}

[1] Anohina, A. (2005). Analysis of the terminology used in the field of virtual learning. Educational Technology \& Society, 8(3), 91-102. 
[2] Beasley, Robert E. (2009). Short Message Service (SMS) Texting Symbols: A Functional Analysis of 10,000 Cellular Phone Text Messages. The Reading Matrix, 9 (2). Retrieved September 9, 2010 from: www.readingmatrix.com/articles/sept_2009/beasley.pdf

[3] Cavus, N. and Ibrahim, D. (2009). M-Learning: An experiment in using SMS to support learning new English language words . British Journal of Educational Technology. 40(1), 78-91.

[4] Chabra, T., Figueiredo, J., (2002). How To Design and Deploy Handheld Learning. Retrieved November 12, 2002 from: http://www.empoweringtechnologies.net/eLearning/eLearning_expov5_files/frame.htm

[5] Chinnery, G.M. (2006). Emerging technologies: going to the MALL (Mobile Assisted Language Learning). Language Learning \& Technology, 10, 9-16.

[6] Fowler, W.S. \& Coe, N. (1976). Nelson English Language Tests. Nelson ELT.

[7] Hulstijn, J.H., \& Laufer B.(2001). Some empirical evidence for the involvement load hypotheses in vocabulary acquisition. Language Learning. . 51,539-558.

[8] Levy, M., Kennedy, C. (2005). 'Learning Italian via mobile SMS', in A. Kukulska-Hulme, \& j. Traxler (ed.) Mobile learning: A Handbook of Educators and Trainers, Abingdon: Rutledge.

[9] Lomine, L., \& Buckingham, C. (2009). M-Learning. Texting (SMS) as a teaching and learning tool in higher arts education. Winchester University, Faculty of Arts, UK.

[10] Lu, M. (2008). Effectiveness of vocabulary learning via mobile phone. Journal of Computer Assisted Learning, 24: 515-525.

[11] Nation, I.S.P. (2001). Learning Vocabulary in another Language. Cambridge University Press, UK.

[12] Prenskey, M.(2005). What can you learn from a cell phone? Almost anything! The Innovative Gateway 1(June/July). Retrieved July 23, 2010 from: http://www.innovateonline.info/index.php

[13] Rozgiene,I., Medvedeva,O., Strakova, Z. (2008). Integrating ICT into language learning and teaching: Guide for tutors. Retrieved November 10, 2010 from: http://www. elexforum.etqm.ae/Proceeding

[14] Thornbury, S. (2004). How to teach vocabulary. Longman: Pearson Education Limited.

[15] Thornton P. \& Houser C. (2003). Using mobile web and video phones in English language teaching: projects with Japanese college students. In Directions in CALL: Experience, Experiments \& Evaluation (eds. B. Morrison, C. Green \& G. Motteram), pp. 207-224. English Language Centre, Hong Kong Polytechnic University, Hong Kong.

[16] Thornton P. \& Houser C. (2004). Using mobile phones in education. Proceedings of the Second International Workshop on Wireless and Mobile Technologies in Education, pp. 3-10. IEEE Computer Society, Jungli, Taiwan.

[17] Thornton P. \& Houser C. (2005). Using mobile phones in English education in Japan. Journal of Computer Assisted Learning $21,217-228$.

Khalil Motallebzadeh is assistant professor at the Islamic Azad University (IAU) of Torbat-e-Heidarieh and Mashhad Branches, Iran. He is a widely published established researcher in language testing and e-learning. He has been a visiting scholar at the University of Illinois at Urbana Champaign (UIUC) in 2007-2008. He is also an accredited teacher trainer of the British Council since 2008 and is currently the Iran representative of Asia TEFL.

Razyeh Ganjali is instructor at the Islamic Azad University (IAU) of Mashhad Branch, Iran. She is interested in e-learning, teaching methodology, and ESP. 